\title{
Impact of hematological inflammatory markers on clinical outcome in patients with salivary duct carcinoma: a multi- institutional study in Japan
}

\author{
Daisuke Kawakita ${ }^{1}$, Yuichiro Tada ${ }^{2}$, Yorihisa Imanishi ${ }^{3}$, Shintaro Beppu ${ }^{1}$, Kiyoaki \\ Tsukahara ${ }^{4}$, Satoshi Kano ${ }^{5}$, Hiroyuki Ozawa ${ }^{3}, K^{2}$ ji Okami ${ }^{6}$, Yuichiro Sato7, Akira \\ Shimizu4, Yukiko Sato ${ }^{8}$, Chihiro Fushimi' ${ }^{2}$, Soichiro Takase ${ }^{4}$, Takuro Okada², Hiroki \\ Sato ${ }^{4}$ Kuninori Otsuka ${ }^{3}$, Yoshihiro Watanabe ${ }^{3}$, Akihiro Sakai ${ }^{6}$, Koji Ebisumoto ${ }^{6}$, \\ Takafumi Togashi, Yushi Ueki, Hisayuki Ota', Tomotaka Shimura9', Toyoyuki \\ Hanazawa $^{10}$, Shingo Murakami ${ }^{1}$, Toshitaka Nagao ${ }^{9}$ \\ ${ }^{1}$ Department of Otorhinolaryngology, Head and Neck Surgery, Nagoya City University Graduate School of Medical Sciences, \\ Nagoya, Japan \\ ${ }^{2}$ Department of Head and Neck Oncology and Surgery, International University of Health and Welfare Mita Hospital, Tokyo, \\ Japan \\ ${ }^{3}$ Department of Otorhinolaryngology-Head and Neck Surgery, Keio University School of Medicine, Tokyo, Japan \\ ${ }^{4}$ Department of Otolaryngology, Tokyo Medical University School of Medicine, Tokyo, Japan \\ ${ }^{5}$ Department of Otorhinolaryngology-Head and Neck Surgery, Hokkaido University Graduate School of Medicine, Sapporo, \\ Japan \\ ${ }^{6}$ Department of Otolaryngology-Head and Neck Surgery, Tokai University School of Medicine, Isehara, Japan \\ ${ }^{7}$ Department of Head and Neck Surgery, Niigata Cancer Center Hospital, Niigata, Japan \\ ${ }^{8}$ Department of Pathology, Cancer Institute Hospital, Japanese Foundation for Cancer Research, Tokyo, Japan \\ ${ }^{9}$ Department of Anatomic Pathology, Tokyo Medical University School of Medicine, Tokyo, Japan \\ ${ }^{10}$ Department of Otolaryngology, Head and Neck Surgery, Chiba University Graduate School of Medicine, Chiba, Japan \\ Correspondence to: Daisuke Kawakita, email: dk200811@gmail.com
}

Keywords: salivary duct carcinoma, survival, mGPS, CRP, NLR

Received: August 26, $2016 \quad$ Accepted: November 09, $2016 \quad$ Published: November 24, 2016

\section{ABSTRACT}

The prognostic role of modified Glasgow Prognostic Score (mGPS), neutrophilto-lymphocyte ratio (NLR) and platelet-to-lymphocyte ratio (PLR) in patients with salivary duct carcinoma (SDC) remains unclear. We conducted a multi-institutional retrospective cohort study of 140 SDC patients. The survival impact of these hematological markers was evaluated using multivariate proportional hazard models. High mGPS ( $\geq 1)$ was significantly associated with worse survival (3-year overall survival (OS): $16.7 \%$ vs $66.1 \%$, $p$-value $=0.003 ; 3$-year progression-free survival (PFS): $0.0 \%$ vs $27.9 \%$, $p$-value $<0.001$ ). Additionally, high C-reactive protein (CRP) ( $\geq 0.39 \mathrm{mg} / \mathrm{dl}$ ) was significantly associated with worse survival (3-year OS: $32.1 \%$ vs $68.2 \%$, $p$-value $=0.001$; 3 -year PFS: $7.1 \%$ vs $31.1 \%$, $p$-value $<0.001$ ). These associations were consistent with multivariate analysis adjusted for established prognostic factors. Although we also found significant association of high NLR ( $\geq 2.5)$ with OS (HR 1.80; 95\% confidence interval, 1.05-3.08) in multivariate analysis, this association were inconsistent with the results of PFS. In addition, we found no significant associations of PLR with survival. In conclusion, we found that mGPS, CRP and NLR were identified as prognostic factors associated with survival in SDC patients. 


\section{INTRODUCTION}

Salivary duct carcinoma (SDC) arises from the ductal epithelium of the salivary gland and accounts for approximately $10 \%$ of all salivary gland malignancies $[1,2]$. On pathological examination, the tumor resembles breast ductal carcinoma, and is characterized by ductal formation with a solid, cystic, cribriform, or papillary structure; elements of intraductal comedonecrosis; calcification; and a reactive desmoplastic stroma [14]. SDC is one of the most aggressive salivary gland malignancies, and prognosis remains poor due to the high incidence of locoregional recurrence and distant metastasis [5-11]. Several evaluations of clinical factors associated with survival in patients with SDC [4-10, 12$16]$ have reported prognostic values for age $(<50$ years) [12], primary tumor size $[6,7,12,15,16]$, and lymph node involvement $[6,8,12,13,15]$. However, further detailed study of these prognostic factors is required to establish individual treatment strategies in SDC patients.

Recent studies have described the impact of several hematological inflammatory and nutritional markers on survival in a number of cancers, including head and neck cancer (HNC). These markers include the Glasgow prognostic score (GPS) or modified Glasgow prognostic score (mGPS), neutrophil-to-lymphocyte ratio (NLR) and platelet-to-lymphocyte ratio (PLR) [17-44]. These factors indicate nutritional and functional decline in patients with malignancies and are associated with poorer outcomes independent of clinical disease stage [20]. To date, however, the association between these factors and SDC survival has not been reported.

Here, to clearly identify these associations with adequate statistical power, we conducted a largescale retrospective cohort study in a multi-institutional investigation setting in Japan.

\section{RESULTS}

\section{Patient characteristics and survival}

Table 1 summarizes the characteristics of the 140 SDC patients evaluated in this study. Median age was 64 years (range, 26-84 years) and median followup time was 3.3 years (range, $0.04-19.0$ years). Males were predominant $(86 \%)$. Primary tumor site was the parotid gland in 109 cases $(78 \%)$, submandibular gland in 28 cases (20\%), and others in 3 cases (2\%). Regarding clinical disease stage, T4 and N2 were most common. Definitive surgery was performed for almost all cases. Carcinoma ex pleomorphic adenoma (CXPA) status was de novo in 53 cases (38\%), invasive CXPA in 68 cases (49\%), and non or micro invasive CXPA in 17 cases (12\%). The 3-year overall survival (OS) among all patients was $65.5 \%$ (95\% confidence interval (CI), 56.6-72.9), and 3 -year progression-free survival (PFS) was $32.0 \%(95 \%$ CI, 24.3-40.0).

\section{Cut-off value of hematological markers in SDC patients}

The cut-off value of hematological markers against clinical outcome in SDC patients was evaluated from the sensitivity, specificity, positive likelihood ratio, and negative likelihood ratio of the serial cut-off values. As only one patient had low albumin $(<3.5 \mathrm{~g} / \mathrm{dl})$ in this study, we decided not to evaluate the optimal cut-off value of albumin. Optimal cut-off values of hematological markers were $0.39 \mathrm{mg} / \mathrm{dl}$ for C-reactive protein (CRP), 2.5 for NLR and 186.2 for PLR. Detailed information on all cutoff values are shown in Supplementary Table S1.

\section{Impact of hematological markers on survival}

Figure 1 shows the association between mGPS and clinical outcomes in patients with SDC using KaplanMeier survival curves. High mGPS $(\geq 1)$ was significantly associated with worse OS and PFS compared with low mGPS (=0) [3-year OS: $16.7 \%$ (95\% CI, 0.01-51.7) vs $66.1 \%$ (95\% CI, 54.5-75.4), $p$-value $=0.003$; 3-year PFS: $0.0 \%$ vs $27.9 \%$ (95\% CI, 18.6-38.0), $p$-value $<0.001]$. Additionally, Figure 2 shows the association between CRP and clinical outcomes in patients with SDC using KaplanMeier survival curves; as with mGPS, high CRP $(\geq 0.39$ $\mathrm{mg} / \mathrm{dl}$ ) was significantly associated with worse OS and PFS compared with low CRP $(<0.39 \mathrm{mg} / \mathrm{dl})$ [3-year OS: $32.1 \%$ (95\% CI, $10.2-56.9)$ vs $68.2 \%$ (95\% CI, 56.8-77.1), $p$-value $=0.001$; 3-year PFS: 7.1\% (95\% CI, 0.01-27.5) vs $31.1 \%$ (95\% CI, 21.4-41.2), $p$-value $<0.001]$.

Table 2 shows the results of uni- and multivariate analysis of hematological markers for clinical outcome in SDC patients. In multivariate analysis adjusted by other general clinical factors, hazard ratios (HRs) for the high mGPS $(\geq 1)$ group relative to the low group $(=0)$ were $4.68(95 \% \mathrm{CI}, 1.22-17.91 ; p$-value $=0.024)$ for OS and $3.92(95 \%$ CI, $1.23-12.49$; $p$-value $=0.021)$ for PFS, respectively. In addition, HRs for the high CRP group $(\geq 0.39 \mathrm{mg} / \mathrm{dl})$ relative to the low group $(<0.39 \mathrm{mg} / \mathrm{dl})$ were $2.45(95 \%$ CI, $1.14-5.30$; $p$-value $=0.022)$ for OS and $2.53(95 \%$ CI, $1.28-5.00$; $p$-value $=0.007)$ for PFS, respectively. Although we found significant association of high NLR $(\geq 2.5)$ with OS (HR 1.80; 95\% CI, 1.05-3.08; $p$-value $=0.032$ ), this association was inconsistent with the results of PFS. Regarding to PLR, we found no significant associations with survival.

\section{Interaction between mGPS, CRP and other clinical factors}

We examined interactions between mGPS, CRP and other clinical factors of SDC (Table 3). For OS, no significant interactions with other clinical factors were found. However, for PFS, significant interactions were observed between mGPS, primary tumor site and N classification, and CRP and sex. For mGPS, the impact 
Table 1: Patient characteristics

\begin{tabular}{|c|c|c|}
\hline Characteristics & $\mathrm{N}(=140)$ & $\%$ \\
\hline \multicolumn{3}{|l|}{ Age } \\
\hline Median (range) & $64(26-84)$ & \\
\hline \multicolumn{3}{|l|}{ Sex } \\
\hline Male & 120 & 86 \\
\hline Female & 20 & 14 \\
\hline \multicolumn{3}{|l|}{$T$ classification } \\
\hline 1 & 12 & 9 \\
\hline 2 & 37 & 26 \\
\hline 3 & 28 & 20 \\
\hline $4 a$ & 61 & 44 \\
\hline $4 \mathrm{~b}$ & 2 & 1 \\
\hline \multicolumn{3}{|l|}{$\mathbf{N}$ classification } \\
\hline 0 & 65 & 46 \\
\hline 1 & 8 & 6 \\
\hline 2 & 66 & 47 \\
\hline 3 & 1 & 1 \\
\hline \multicolumn{3}{|l|}{ M classification } \\
\hline 0 & 130 & 93 \\
\hline 1 & 10 & 7 \\
\hline \multicolumn{3}{|l|}{ Primary tumor site } \\
\hline Parotid gland & 109 & 78 \\
\hline Submandibular gland & 28 & 20 \\
\hline Others & 3 & 2 \\
\hline \multicolumn{3}{|l|}{ First-line treatment } \\
\hline Surgery & 137 & 98 \\
\hline Radiotherapy & 3 & 2 \\
\hline \multicolumn{3}{|l|}{ CXPA status } \\
\hline de novo & 53 & 38 \\
\hline CXPA invasion & 68 & 49 \\
\hline CXPA non or micro invasion & 17 & 12 \\
\hline unknown & 2 & 1 \\
\hline
\end{tabular}

Abbreviation: CXPA, carcinoma ex pleomorphic adenoma.

of high mGPS on PFS was stronger in patients with the parotid gland and N0. In addition, because the number of cases was low, we could not estimate the ORs of high CRP for females. Finally, HRs for both mGPS and CRP were higher in CXPA cases than in de novo cases, albeit without significance.

\section{DISCUSSION}

In this study, we found that high mGPS, CRP and NLR before treatment were significantly associated with poor survival in SDC patients. To our knowledge, this is the first study to identify these associations and suggests that the investigation of mGPS, CRP and NLR before treatment may be effective for the selection of high-risk SDC patients.

Although the mechanism behind these associations between hematological markers associated with systemic inflammation and nutrition and the prognosis of SDC is unclear, some possibilities can be mentioned based on previous evidence. First, elevated these hematological markers may be surrogate markers of pre-cancer 

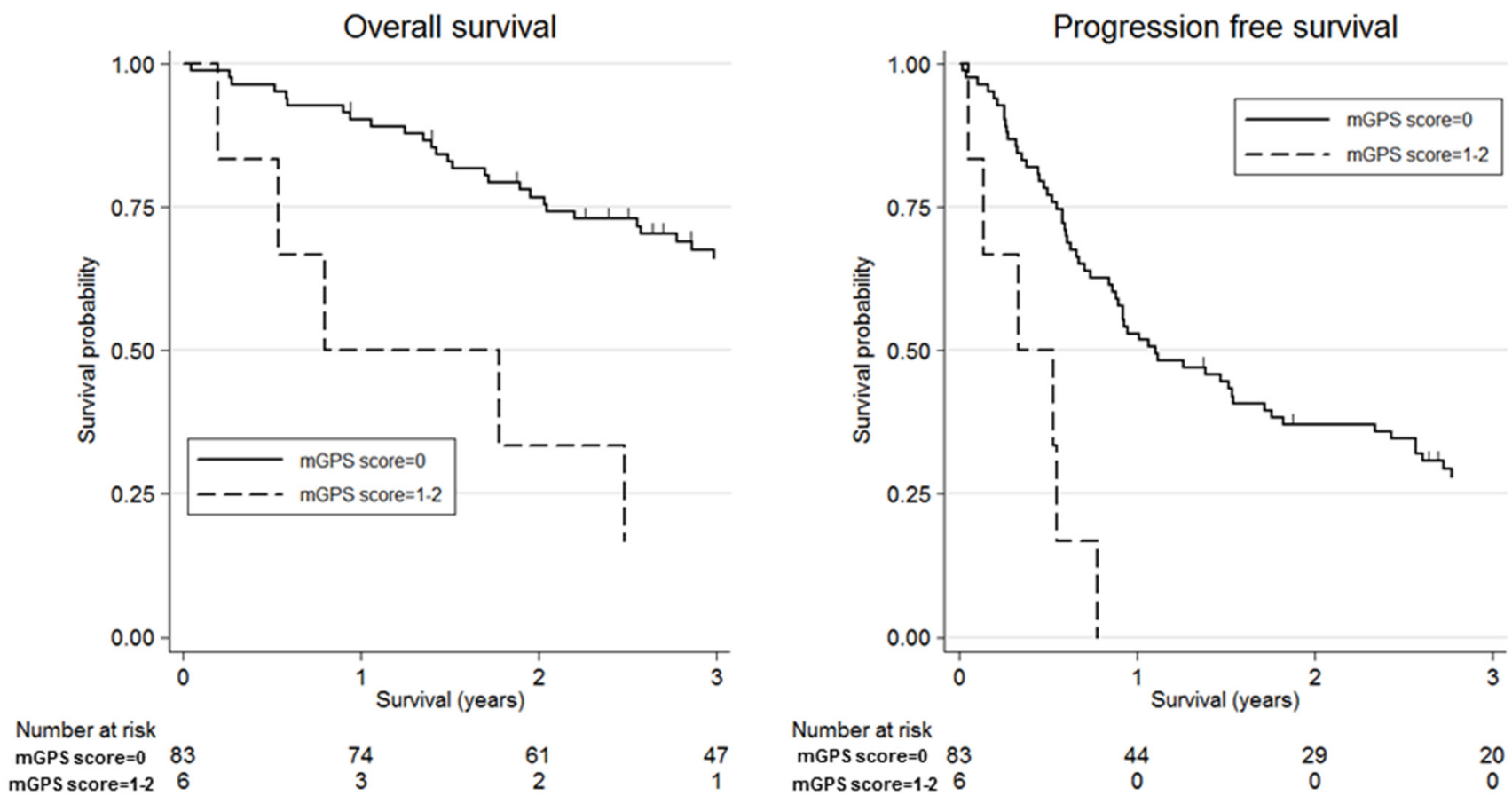

Figure 1: Kaplan-Meier survival curves according to modified Glasgow Prognostic Score (mGPS). Three-year overall survival was $16.7 \%$ (95\% confidence interval (CI): 0.01-51.7) for high mGPS ( $\geq 1)$ and $66.1 \%$ (95\% CI: 54.5-75.4) for low mGPS $(=0)(\log$ rank test, $p$-value $=0.003)$. Three-year progression-free survival was $0.0 \%$ for high mGPS and $27.9 \%$ (95\% CI: 18.6-38.0) for low mGPS (log-rank test, $p$-value $<0.001$ ).
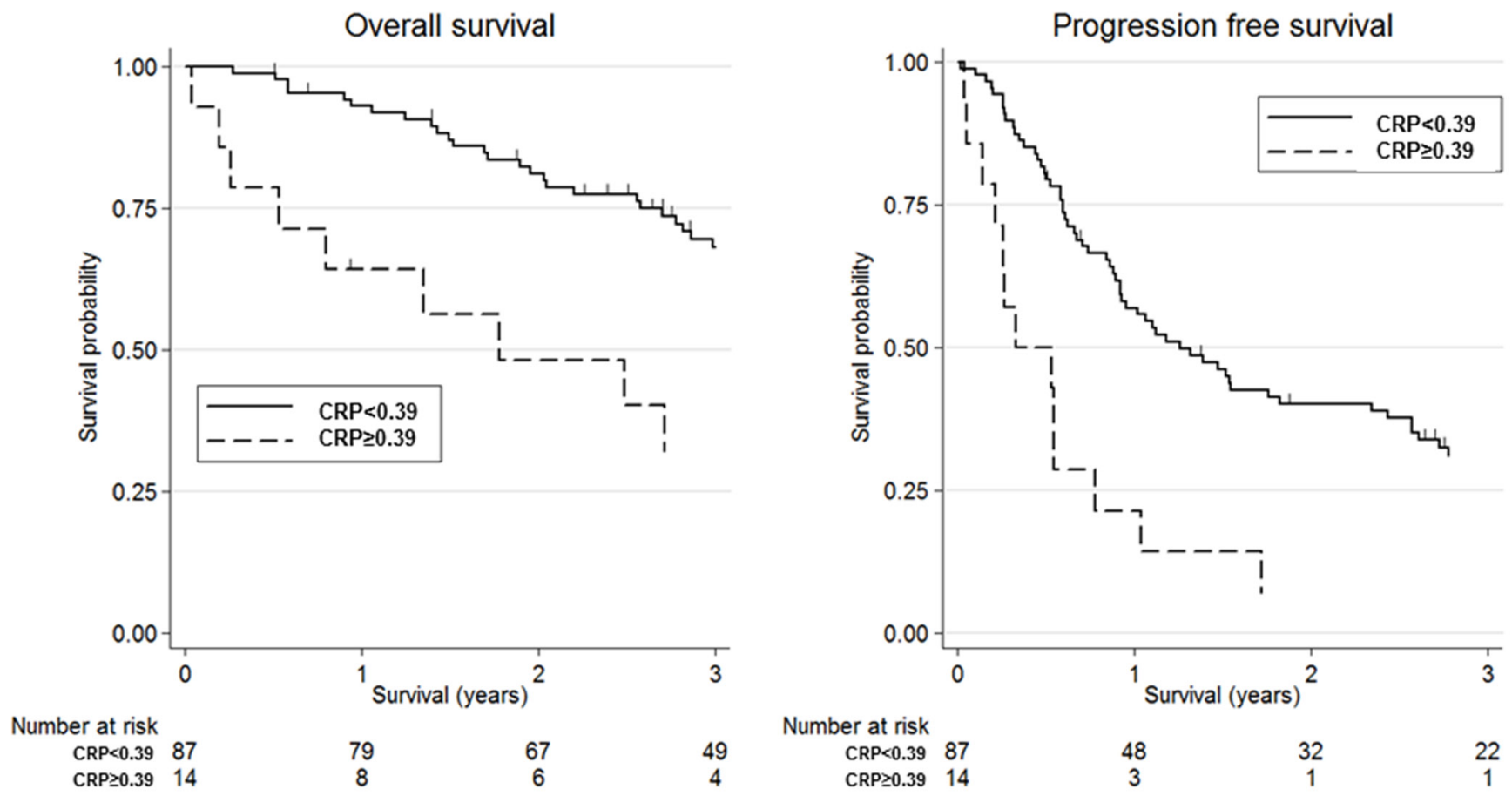

Figure 2: Kaplan-Meier survival curves according to C-reactive protein (CRP). Three-year overall survival was $32.1 \%$ (95\% confidence interval (CI): 10.2-56.9) for high CRP $(\geq 0.39 \mathrm{mg} / \mathrm{dl})$ and $68.2 \%$ (95\% CI: 56.8-77.1) for low CRP( $<0.39 \mathrm{mg} / \mathrm{dl})(\mathrm{log}-\mathrm{rank}$ test, $p$-value $=0.001)$. Three-year progression-free survival was 7.1\% (95\% CI: $0.01-27.5)$ for high CRP and 31.1\% (95\% CI: $21.4-41.2)$ for low CRP (log-rank test, $p$-value $<0.001)$. 
Table 2: Univariate and multivariate analysis of clinical outcomes in patients with salivary duct carcinoma

\begin{tabular}{|c|c|c|c|c|c|c|c|c|c|c|c|c|c|}
\hline \multirow{3}{*}{$\begin{array}{l}\text { Inflammatory } \\
\text { markers }\end{array}$} & \multirow{3}{*}{$\mathbf{N}$} & \multicolumn{6}{|c|}{ Overall survival } & \multicolumn{6}{|c|}{ Progression-free survival } \\
\hline & & \multicolumn{3}{|c|}{ Univariate analysis } & \multicolumn{3}{|c|}{ Multivariate analysis } & \multicolumn{3}{|c|}{ Univariate analysis } & \multicolumn{3}{|c|}{ Multivariate analysis } \\
\hline & & HR & $\begin{array}{c}95 \% \\
\text { CI }\end{array}$ & $p$-values & HR & $\begin{array}{c}95 \% \\
\text { CI }\end{array}$ & $p$-values & HR & $\begin{array}{c}95 \% \\
\text { CI }\end{array}$ & $p$-values & HR & $\begin{array}{c}95 \% \\
\text { CI }\end{array}$ & $p$-values \\
\hline \multicolumn{14}{|l|}{ mGPS } \\
\hline 0 & 83 & 1.00 & - & reference & 1.00 & - & reference & 1.00 & - & reference & 1.00 & - & reference \\
\hline $1-2$ & 6 & 3.83 & $\begin{array}{l}1.50- \\
9.80\end{array}$ & 0.005 & 4.68 & $\begin{array}{l}1.22- \\
17.91\end{array}$ & 0.024 & 4.66 & $\begin{array}{l}1.95- \\
11.13\end{array}$ & 0.001 & 3.92 & $\begin{array}{l}1.23- \\
12.49\end{array}$ & 0.021 \\
\hline unknown & 51 & 0.92 & $\begin{array}{c}0.55- \\
1.54\end{array}$ & 0.745 & 1.32 & $\begin{array}{l}0.75- \\
2.34\end{array}$ & 0.340 & 0.73 & $\begin{array}{c}0.47- \\
1.13\end{array}$ & 0.155 & 0.85 & $\begin{array}{c}0.52- \\
1.38\end{array}$ & 0.509 \\
\hline \multicolumn{14}{|l|}{ CRP (mg/dl) } \\
\hline$<0.39$ & 87 & 1.00 & - & reference & 1.00 & - & reference & 1.00 & - & reference & 1.00 & - & reference \\
\hline$\geq 0.39$ & 14 & 3.04 & $\begin{array}{l}1.55- \\
5.97\end{array}$ & 0.001 & 2.45 & $\begin{array}{l}1.14- \\
5.30\end{array}$ & 0.022 & 2.93 & $\begin{array}{l}1.59- \\
5.38\end{array}$ & 0.001 & 2.53 & $\begin{array}{l}1.28- \\
5.00\end{array}$ & 0.007 \\
\hline unknown & 39 & 1.08 & $\begin{array}{c}0.62- \\
1.88\end{array}$ & 0.791 & 1.86 & $\begin{array}{l}0.99- \\
3.51\end{array}$ & 0.056 & 0.80 & $\begin{array}{c}0.50- \\
1.28\end{array}$ & 0.350 & 1.03 & $\begin{array}{c}0.62- \\
1.72\end{array}$ & 0.896 \\
\hline \multicolumn{14}{|l|}{ NLR } \\
\hline$<2.5$ & 84 & 1.00 & - & reference & 1.00 & - & reference & 1.00 & - & reference & 1.00 & - & reference \\
\hline$\geq 2.5$ & 49 & 1.98 & $\begin{array}{l}1.20- \\
3.25\end{array}$ & 0.007 & 1.80 & $\begin{array}{l}1.05- \\
3.08\end{array}$ & 0.032 & 1.27 & $\begin{array}{c}0.84- \\
1.93\end{array}$ & 0.261 & 1.00 & $\begin{array}{c}0.63- \\
1.59\end{array}$ & 0.994 \\
\hline unknown & 7 & 2.40 & $\begin{array}{c}0.99- \\
5.81\end{array}$ & 0.053 & 2.57 & $\begin{array}{l}0.95- \\
6.95\end{array}$ & 0.063 & 1.39 & $\begin{array}{l}0.60- \\
3.24\end{array}$ & 0.442 & 1.50 & $\begin{array}{l}0.61- \\
3.71\end{array}$ & 0.378 \\
\hline \multicolumn{14}{|l|}{ PLR } \\
\hline$<186.2$ & 105 & 1.00 & - & reference & 1.00 & - & reference & 1.00 & - & reference & 1.00 & - & reference \\
\hline$\geq 186.2$ & 28 & 1.98 & $\begin{array}{l}1.15- \\
3.39\end{array}$ & 0.013 & 1.82 & $\begin{array}{c}0.98- \\
3.36\end{array}$ & 0.057 & 1.36 & $\begin{array}{l}0.83- \\
2.22\end{array}$ & 0.219 & 1.04 & $\begin{array}{c}0.61- \\
1.78\end{array}$ & 0.885 \\
\hline unknown & 7 & 2.17 & $\begin{array}{c}0.91- \\
5.15\end{array}$ & 0.080 & 2.47 & $\begin{array}{c}0.92- \\
6.62\end{array}$ & 0.072 & 1.35 & $\begin{array}{c}0.59- \\
3.12\end{array}$ & 0.477 & 1.52 & $\begin{array}{c}0.62- \\
3.74\end{array}$ & 0.361 \\
\hline
\end{tabular}

Adjusted by age, sex, primary tumor site, TNM classification, first-line treatment, CXPA status.

Abbreviations: mGPS, modified Glasgow Prognostic Score; CRP, C-reactive protein; NLR, neutrophil-to-lymphocyte ratio; PLR, platelet-to-lymphocyte ratio; HR, hazard ratio; CXPA, carcinoma ex pleomorphic adenoma; CI, confidence interval.

cachexia, which is characterized by increased weight loss, poor performance status, increased comorbidity, increased pro-inflammatory and angiogenic cytokines, and complications on treatment [20]. It has been noted that cancer cachexia is associated with poor survival [45-47]. Second, inflammation in the tumor microenvironment causes a range of aggressive tumor behaviors, including proliferation and survival of tumor cells, promotion of metastasis and angiogenesis, host immune deficiency, and alteration of responses to hormones and chemotherapeutic agents [48, 49].

To date, we are aware of at least 23 studies that have evaluated the association between GPS or mGPS, NLR, PLR and survival in patients with HNC [22-44]. Although most studies indicated that these factors had significant prognostic impact, one study each of NLR [25] and PLR
[44] showed no significant association with survival. In the present study, although we detected significant association of NLR with OS in SDC patients, we could not find significant association with PFS. According to PLR, We also found the similar association with OS and PFS. Therefore, we evaluated the associations of NLR and PLR with disease-specific survival (DSS), and found significant associations of these factors with DSS (data not shown). According to this results, we interpreted that NLR and PLR might be associated with poor survival after progressin of tumor. Although the reason for this inconsistency is difficult to determine, a recent study suggested that mGPS might be superior to NLR and PLR in patients with nasopharyngeal cancer [22]. Additionally, since our cohort included only one case with low albumin, CRP might be a better indicator of prognosis than mGPS 
Table 3: Interaction between systemic inflammatory markers and clinical characteristics on clinical outcomes in patients with salivary duct carcinoma

\begin{tabular}{|c|c|c|c|c|c|c|c|c|c|c|c|c|c|c|c|c|c|c|c|c|}
\hline \multirow{3}{*}{ Characteristics } & \multicolumn{10}{|c|}{ Overall survival } & \multicolumn{10}{|c|}{ Progression-free survival } \\
\hline & \multicolumn{5}{|c|}{ mGPS ( $\geq 1)$} & \multicolumn{5}{|c|}{$\mathrm{CRP}(\geq 0.39 \mathrm{mg} / \mathrm{dl})$} & \multicolumn{5}{|c|}{ mGPS ( $\geq 1)$} & \multicolumn{5}{|c|}{$\mathrm{CRP}(\geq 0.39 \mathrm{mg} / \mathrm{dl})$} \\
\hline & $\mathbf{N}$ & HR & $\begin{array}{c}95 \% \\
\text { CI }\end{array}$ & $\begin{array}{c}p \text { - } \\
\text { values }\end{array}$ & $\begin{array}{c}p_{\text {for }} \\
\text { heterogeneity }\end{array}$ & $\mathbf{N}$ & HR & $\begin{array}{c}95 \% \\
\text { CI }\end{array}$ & $\begin{array}{c}p- \\
\text { values }\end{array}$ & $\begin{array}{c}p_{\text {for }} \\
\text { heterogeneity }\end{array}$ & $\mathbf{N}$ & HR & $\begin{array}{c}95 \% \\
\text { CI }\end{array}$ & $\begin{array}{c}p \text { - } \\
\text { values }\end{array}$ & $\begin{array}{c}p_{\text {for }} \\
\text { heterogeneity }\end{array}$ & $\mathbf{N}$ & HR & $\begin{array}{c}95 \% \\
\text { CI }\end{array}$ & $\begin{array}{c}p- \\
\text { values }\end{array}$ & $\begin{array}{c}p_{\text {for }} \\
\text { heterogeneity }\end{array}$ \\
\hline \multicolumn{21}{|l|}{ Age } \\
\hline$<65$ & 45 & 6.94 & $\begin{array}{l}0.61- \\
79.36\end{array}$ & 0.119 & 0.623 & 52 & 2.55 & $\begin{array}{l}0.63- \\
10.34\end{array}$ & 0.189 & 0.623 & 45 & 5.20 & $\begin{array}{l}0.89- \\
30.42\end{array}$ & 0.068 & 0.869 & 52 & 1.64 & $\begin{array}{l}0.53- \\
5.13\end{array}$ & 0.394 & 0.364 \\
\hline$\geq 65$ & 44 & 3.36 & $\begin{array}{l}0.34- \\
33.08\end{array}$ & 0.299 & & 49 & 3.00 & $\begin{array}{l}1.00- \\
9.04\end{array}$ & 0.051 & & 44 & 4.44 & $\begin{array}{l}0.39- \\
50.66\end{array}$ & 0.230 & & 49 & 3.83 & $\begin{array}{l}1.46- \\
10.07\end{array}$ & 0.006 & \\
\hline \multicolumn{21}{|l|}{ Sex } \\
\hline Male & 78 & 4.03 & $\begin{array}{l}1.10- \\
14.80\end{array}$ & 0.036 & 0.544 & 87 & 2.41 & $\begin{array}{l}1.06- \\
5.47\end{array}$ & 0.036 & 0.106 & 78 & 4.14 & $\begin{array}{l}1.39- \\
12.38\end{array}$ & 0.011 & 0.441 & 87 & 1.94 & $\begin{array}{l}0.97- \\
3.89\end{array}$ & 0.062 & 0.034 \\
\hline Female & 11 & $\mathrm{NE}$ & - & - & & 14 & NE & - & - & & 11 & $\mathrm{NE}$ & - & - & & 14 & NE & - & - & \\
\hline \multicolumn{21}{|l|}{$\begin{array}{l}\text { Primary tumor } \\
\text { site }\end{array}$} \\
\hline $\begin{array}{l}\text { Parotid } \\
\text { gland }\end{array}$ & 65 & 20.23 & $\begin{array}{c}3.27- \\
125.17\end{array}$ & 0.001 & 0.103 & 75 & 3.78 & $\begin{array}{l}1.58- \\
9.03\end{array}$ & 0.003 & 0.144 & 65 & 28.26 & $\begin{array}{c}5.27- \\
151.64\end{array}$ & $<0.001$ & 0.045 & 75 & 2.87 & $\begin{array}{l}1.28- \\
6.48\end{array}$ & 0.011 & 0.344 \\
\hline Others & 24 & 2.52 & $\begin{array}{l}0.09- \\
70.79\end{array}$ & 0.586 & & 26 & 1.13 & $\begin{array}{l}0.10- \\
13.19\end{array}$ & 0.922 & & 24 & 3.43 & $\begin{array}{l}0.46- \\
25.85\end{array}$ & 0.231 & & 26 & 1.35 & $\begin{array}{l}0.32- \\
5.68\end{array}$ & 0.682 & \\
\hline \multicolumn{21}{|l|}{$\begin{array}{l}\mathrm{T} \\
\text { classification }\end{array}$} \\
\hline $1-2$ & 32 & 21.82 & $\begin{array}{c}2.01- \\
236.49\end{array}$ & 0.011 & 0.377 & 35 & 6.65 & $\begin{array}{l}0.85- \\
52.12\end{array}$ & 0.072 & 0.531 & 32 & 22.79 & $\begin{array}{c}2.24- \\
231.49\end{array}$ & 0.008 & 0.817 & 35 & 12.52 & $\begin{array}{c}1.47- \\
106.67\end{array}$ & 0.021 & 0.662 \\
\hline $3-4$ & 57 & 4.64 & $\begin{array}{l}0.65- \\
33.01\end{array}$ & 0.125 & & 66 & 2.85 & $\begin{array}{l}1.23- \\
6.57\end{array}$ & 0.014 & & 57 & 3.24 & $\begin{array}{l}0.81- \\
12.98\end{array}$ & 0.097 & & 66 & 2.71 & $\begin{array}{l}1.32- \\
5.56\end{array}$ & 0.006 & \\
\hline \multicolumn{21}{|l|}{$\begin{array}{l}\mathrm{N} \\
\text { classification }\end{array}$} \\
\hline 0 & 40 & 51.96 & $\begin{array}{c}5.04- \\
535.29\end{array}$ & 0.001 & 0.103 & 43 & 5.41 & $\begin{array}{l}1.04- \\
28.24\end{array}$ & 0.045 & 0.377 & 40 & 220.04 & $\begin{array}{c}17.81- \\
2718.82\end{array}$ & $<0.001$ & 0.045 & 43 & 10.72 & $\begin{array}{l}2.12- \\
54.04\end{array}$ & 0.004 & 0.128 \\
\hline$>1$ & 49 & 1.92 & $\begin{array}{l}0.18- \\
20.62\end{array}$ & 0.590 & & 58 & 2.49 & $\begin{array}{c}0.95- \\
6.51\end{array}$ & 0.064 & & 49 & 1.84 & $\begin{array}{l}0.33- \\
10.18\end{array}$ & 0.486 & & 58 & 1.65 & $\begin{array}{l}0.71- \\
3.82\end{array}$ & 0.247 & \\
\hline \multicolumn{21}{|l|}{ M classification } \\
\hline 0 & 81 & 3.20 & $\begin{array}{l}0.68- \\
15.03\end{array}$ & 0.141 & 0.316 & 93 & 2.44 & $\begin{array}{l}1.10- \\
5.41\end{array}$ & 0.028 & 0.400 & 81 & 4.35 & $\begin{array}{l}1.13- \\
16.70\end{array}$ & 0.032 & 0.632 & 93 & 2.09 & $\begin{array}{l}1.01- \\
4.36\end{array}$ & 0.048 & 0.653 \\
\hline 1 & 8 & $\mathrm{NE}$ & - & - & & 8 & $\mathrm{NE}$ & - & - & & 8 & $\mathrm{NE}$ & - & - & & 8 & $\mathrm{NE}$ & - & - & \\
\hline \multicolumn{21}{|l|}{$\begin{array}{l}\text { First-line } \\
\text { treatment }\end{array}$} \\
\hline Surgery & 86 & 4.33 & $\begin{array}{l}1.18- \\
15.91\end{array}$ & 0.027 & 0.886 & 98 & 2.85 & $\begin{array}{l}1.33- \\
6.11\end{array}$ & 0.007 & 0.551 & 86 & 3.53 & $\begin{array}{l}1.09- \\
11.38\end{array}$ & 0.035 & 0.999 & 98 & 2.22 & $\begin{array}{l}1.13- \\
4.34\end{array}$ & 0.020 & 0.734 \\
\hline Radiotherapy & 3 & $\mathrm{NE}$ & - & - & & 3 & $\mathrm{NE}$ & - & - & & 3 & $\mathrm{NE}$ & - & - & & 3 & $\mathrm{NE}$ & - & - & \\
\hline \multicolumn{21}{|l|}{ CXPA status } \\
\hline de novo & 35 & 1.34 & $\begin{array}{l}0.08- \\
23.80\end{array}$ & 0.841 & 0.501 & 38 & 1.81 & $\begin{array}{l}0.49- \\
6.76\end{array}$ & 0.375 & 0.456 & 35 & 1.07 & $\begin{array}{l}0.13- \\
8.43\end{array}$ & 0.952 & 0.588 & 38 & 1.31 & $\begin{array}{l}0.41- \\
4.19\end{array}$ & 0.649 & 0.425 \\
\hline CXPA & 53 & 7.99 & $\begin{array}{l}1.34- \\
47.72\end{array}$ & 0.023 & & 62 & 4.98 & $\begin{array}{l}1.72- \\
14.44\end{array}$ & 0.003 & & 53 & 3.51 & $\begin{array}{l}0.61- \\
20.32\end{array}$ & 0.161 & & 62 & 3.02 & $\begin{array}{l}1.12- \\
8.14\end{array}$ & 0.029 & \\
\hline
\end{tabular}

Abbreviations: mGPS, modified Glasgow Prognostic Score; CRP, C-reactive protein; CI, confidence interval; CXPA, carcinoma ex pleomorphic adenoma; NE, not estimatable.

in patients with SDC. These findings indicate that systemic inflammatory and nutritional conditions should be evaluated before treatment. This information might be valuable in the development of individual treatment strategies for patients with SDC, including appropriate supportive care.

Our study has two methodological strengths. First, the clinicians involved in the care of study patients had no information on the association between hematological markers and SDC survival, which likely precluded the introduction of information bias. Second, our sample size is one of the largest among cohort studies in patients with SDC.

Additionally, several limitations of this study warrant mention. First, our information on hematological markers reflected pretreatment status only. Second, we could not completely remove the possibility of infection or other inflammatory conditions. Third, although our sample 
size represents one of the largest cohorts in SDC, the relatively large amount of missing data may have limited the statistical power.

In conclusion, we found significant positive associations of mGPS, CRP and NLR with survival in patients with SDC. These findings provide evidence in support of the development of individual treatment strategies in SDC.

\section{MATERIALS AND METHODS}

\section{Patients}

The study was conducted under a retrospective cohort design in patients with SDC treated at seven hospitals between 1992 and 2014: the International University of Health and Welfare Mita Hospital, Keio University Hospital, Hokkaido University Hospital, Tokyo Medical University Hospital, Tokyo Medical University Hachioji Medical Center, Tokai University Hospital, and Niigata Cancer Center Hospital. The study design was approved by the Institutional Ethics Review Board of each of these hospitals. One hundred and forty SDC patients were enrolled in the study.

\section{Treatment and follow-up}

All samples underwent central pathological review by two expert pathologists (T.N. and Y.S.). Diagnoses were conducted independently, and any disagreements were resolved by discussion. Staging was in accordance with the UICC TNM classification and staging system (2010, 7th edition). Given that no effective chemotherapy regimen for patients with SDC has yet been established, operable cases were treated by definitive surgery with or without neck dissection [6]. Postoperative radiotherapy was performed when the surgical margin was positive or equivocal and/ or lymph node metastasis was pathologically positive. For inoperable cases, we performed palliative radiotherapy or chemotherapy, in consideration of performance status (PS) and comorbidities. Following the end of treatment, patients underwent a medical history and physical examination, complete blood cell count, and imaging examination every 3-6 months. Vital and disease status were confirmed by checking medical records at the date of the last follow-up visit.

\section{Evaluation of hematological inflammatory and nutritional markers}

In this study, we selected several pre-treatment hematological markers associated with systemic inflammatory and nutritional condition, including CRP, serum albumin, complete blood count with circulating neutrophil count, circulating lymphocyte count, circulating platelet count, NLR, and PLR. Regarding mGPS, patients with both an elevated CRP level $(>1.0 \mathrm{mg} / \mathrm{dl})$ and lower albumin $(<3.5 \mathrm{~g} / \mathrm{dl})$ were allocated a score of 2 ; those with an elevated CRP level ( $>1.0 \mathrm{mg} / \mathrm{dl})$ and nondecreased albumin $(\geq 3.5 \mathrm{~g} / \mathrm{dl})$ were allocated a score of 1 ; and those with a non-elevated CRP level $(\leq 1.0 \mathrm{mg} / \mathrm{dl})$ were allocated a score of 0 [20].

\section{Statistical analysis}

Cut-off values for continuous variables of hematological markers in SDC patients were evaluated using the area under the receiver operating characteristic curve (AUROC). We defined overall death as the objective standard and continuous values of the hematological markers as the diagnostic test value.

Primary endpoint was OS, defined as the interval between the beginning of treatment and the date of death or last follow-up. PFS was measured as a secondary endpoint and defined as the number of days from the beginning of treatment to the date of relapse or progression, as evaluated and recorded by the attending physician. The association between hematological markers, OS, and PFS was evaluated by the Kaplan-Meier product-limit method and univariate and multivariate Cox proportional hazards models. The measure of association in this study was HR with a $95 \%$ CI. Confounders considered in the univariate and multivariate analyses were age $(<65$ vs $\geq 65$ ), sex (male vs female), T classification (1/2/3/4), $N$ classification $(0 / 1 / 2 / 3), \mathrm{M}$ classification $(0 / 1)$, primary tumor site (parotid gland vs submandibular gland vs others), first-line treatment (surgery vs radiotherapy), and CXPA status (de novo vs invasive CXPA vs non or micro invasive CXPA). All statistical analyses were performed using STATA version 13 (Stata Corp., College Station, TX, USA). All tests were two-sided, and $p$ values of $<0.05$ were considered statistically significant.

\section{ACKNOWLEDGMENTS}

This work was supported by JSPS Grant-in-Aid for Young Scientists (B) to D. Kawakita (No.15K21283), and Grants-in-Aid for Scientific Research (C) to Y. Tada (No.15K10823), and Y. Imanishi (No.16K11245).

\section{CONFLICTS OF INTEREST}

The authors declare no conflicts of interest.

\section{REFERENCES}

1. Barnes L EJ, Reichart P, Sidaransky D. (2005). World Health Organization classification of tumours. Pathology and genetics of head and neck tumours. (Lyon: IARC Press).

2. McHugh JB, Visscher DW, Barnes EL. Update on selected salivary gland neoplasms. Archives of pathology \& laboratory medicine. 2009; 133:1763-1774. 
3. Etges A, Pinto DS, Jr., Kowalski LP, Soares FA, Araujo VC. Salivary duct carcinoma: immunohistochemical profile of an aggressive salivary gland tumour. Journal of clinical pathology. 2003; 56:914-918.

4. Hosal AS, Fan C, Barnes L, Myers EN. Salivary duct carcinoma. Otolaryngology—head and neck surgery. 2003; 129:720-725.

5. Barnes L, Rao U, Krause J, Contis L, Schwartz A, Scalamogna P. Salivary duct carcinoma. Part I. A clinicopathologic evaluation and DNA image analysis of 13 cases with review of the literature. Oral surgery, oral medicine, and oral pathology. 1994; 78:64-73.

6. Guzzo M, Di Palma S, Grandi C, Molinari R. Salivary duct carcinoma: clinical characteristics and treatment strategies. Head \& neck. 1997; 19:126-133.

7. Delgado R, Vuitch F, Albores-Saavedra J. Salivary duct carcinoma. Cancer. 1993; 72:1503-1512.

8. Lewis JE, McKinney BC, Weiland LH, Ferreiro JA, Olsen KD. Salivary duct carcinoma. Clinicopathologic and immunohistochemical review of 26 cases. Cancer. 1996; 77:223-230

9. Jaehne M, Roeser K, Jaekel T, Schepers JD, Albert N, Loning T. Clinical and immunohistologic typing of salivary duct carcinoma: a report of 50 cases. Cancer. 2005; 103:2526-2533.

10. Roh JL, Lee JI, Choi SH, Nam SY, Kim SO, Cho KJ, Kim SB, Kim SY. Prognostic factors and oncologic outcomes of 56 salivary duct carcinoma patients in a single institution: high rate of systemic failure warrants targeted therapy. Oral oncology. 2014; 50:e64-66.

11. Johnston ML, Huang SH, Waldron JN, Atenafu EG, Chan K, Cummings BJ, Gilbert RW, Goldstein D, Gullane PJ, Irish JC, Perez-Ordonez B, Weinreb I, Bayley A, et al. Salivary duct carcinoma: Treatment, outcomes, and patterns of failure. Head \& neck. 2016; 38:E820-826.

12. Jayaprakash V, Merzianu M, Warren GW, Arshad H, Hicks WL, Jr., Rigual NR, Sullivan MA, Seshadri M, Marshall JR, Cohan DM, Zhao Y, Singh AK. Survival rates and prognostic factors for infiltrating salivary duct carcinoma: Analysis of 228 cases from the Surveillance, Epidemiology, and End Results database. Head \& neck. 2014; 36:694-701.

13. Otsuka K, Imanishi Y, Tada Y, Kawakita D, Kano S, Tsukahara K, Shimizu A, Ozawa H, Okami K, Sakai A, Sato Y, Ueki Y, Sato Y, et al. Clinical Outcomes and Prognostic Factors for Salivary Duct Carcinoma: A Multi-Institutional Analysis of 141 Patients. Annals of surgical oncology. 2016; 23:2038-2045.

14. Kim JY, Lee S, Cho KJ, Kim SY, Nam SY, Choi SH, Roh JL, Choi EK, Kim JH, Song SY, Shin HS, Chang SK, Ahn SD. Treatment results of post-operative radiotherapy in patients with salivary duct carcinoma of the major salivary glands. The British journal of radiology. 2012; 85:e947-952.
15. Brandwein MS, Jagirdar J, Patil J, Biller H, Kaneko M. Salivary duct carcinoma (cribriform salivary carcinoma of excretory ducts). A clinicopathologic and immunohistochemical study of 12 cases. Cancer. 1990; 65:2307-2314.

16. Hui KK, Batsakis JG, Luna MA, Mackay B, Byers RM. Salivary duct adenocarcinoma: a high grade malignancy. The Journal of laryngology and otology. 1986; 100:105-114.

17. Proctor MJ, Talwar D, Balmar SM, O'Reilly DS, Foulis AK, Horgan PG, Morrison DS, McMillan DC. The relationship between the presence and site of cancer, an inflammationbased prognostic score and biochemical parameters. Initial results of the Glasgow Inflammation Outcome Study. British journal of cancer. 2010; 103:870-876.

18. Proctor MJ, Morrison DS, Talwar D, Balmer SM, Fletcher CD, O'Reilly DS, Foulis AK, Horgan PG, McMillan DC. A comparison of inflammation-based prognostic scores in patients with cancer. A Glasgow Inflammation Outcome Study. European journal of cancer. 2011; 47:2633-2641.

19. Partridge M, Fallon M, Bray C, McMillan D, Brown D, Laird B. Prognostication in advanced cancer: a study examining an inflammation-based score. Journal of pain and symptom management. 2012; 44:161-167.

20. McMillan DC. The systemic inflammation-based Glasgow Prognostic Score: a decade of experience in patients with cancer. Cancer treatment reviews. 2013; 39:534-540.

21. Guthrie GJ, Charles KA, Roxburgh CS, Horgan PG, McMillan DC, Clarke SJ. The systemic inflammationbased neutrophil-lymphocyte ratio: experience in patients with cancer. Critical reviews in oncology/hematology. 2013; 88:218-230.

22. Chen C, Sun P, Dai QS, Weng HW, Li HP, Ye S. The Glasgow Prognostic Score predicts poor survival in cisplatin-based treated patients with metastatic nasopharyngeal carcinoma. PloS one. 2014; 9:e112581.

23. Farhan-Alanie OM, McMahon J, McMillan DC. Systemic inflammatory response and survival in patients undergoing curative resection of oral squamous cell carcinoma. The British journal of oral \& maxillofacial surgery. 2015; 53:126-131.

24. Nakayama M, Tabuchi K, Hara A. Clinical utility of the modified Glasgow prognostic score in patients with advanced head and neck cancer. Head \& neck. 2015; 37:1745-1749.

25. Selzer E, Grah A, Heiduschka G, Kornek G, Thurnher D. Primary radiotherapy or postoperative radiotherapy in patients with head and neck cancer: Comparative analysis of inflammation-based prognostic scoring systems. Strahlentherapie und Onkologie. 2015; 191:486-494.

26. An X, Ding PR, Wang FH, Jiang WQ, Li YH. Elevated neutrophil to lymphocyte ratio predicts poor prognosis in nasopharyngeal carcinoma. Tumour biology. 2011; $32: 317-324$. 
27. He JR, Shen GP, Ren ZF, Qin H, Cui C, Zhang Y, Zeng YX, Jia WH. Pretreatment levels of peripheral neutrophils and lymphocytes as independent prognostic factors in patients with nasopharyngeal carcinoma. Head \& neck. 2012; 34:1769-1776.

28. Fang HY, Huang XY, Chien HT, Chang JT, Liao CT, Huang JJ, Wei FC, Wang HM, Chen IH, Kang CJ, Huang SF. Refining the role of preoperative C-reactive protein by neutrophil/lymphocyte ratio in oral cavity squamous cell carcinoma. The Laryngoscope. 2013; 123:2690-2699.

29. Perisanidis C, Kornek G, Poschl PW, Holzinger D, Pirklbauer K, Schopper C, Ewers R. High neutrophil-tolymphocyte ratio is an independent marker of poor diseasespecific survival in patients with oral cancer. Medical oncology (Northwood, London, England). 2013; 30:334.

30. Haddad CR, Guo L, Clarke S, Guminski A, Back M, Eade T. Neutrophil-to-lymphocyte ratio in head and neck cancer. Journal of medical imaging and radiation oncology. 2015; 59:514-519.

31. Jin Y, Ye X, He C, Zhang B, Zhang Y. Pretreatment neutrophil-to-lymphocyte ratio as predictor of survival for patients with metastatic nasopharyngeal carcinoma. Head \& neck. 2015; 37:69-75.

32. Rassouli A, Saliba J, Castano R, Hier M, Zeitouni AG. Systemic inflammatory markers as independent prognosticators of head and neck squamous cell carcinoma. Head \& neck. 2015; 37:103-110.

33. Salim DK, Mutlu H, Eryilmaz MK, Salim O, Musri FY, Tural D, Gunduz S, Coskun HS. Neutrophil to lymphocyte ratio is an independent prognostic factor in patients with recurrent or metastatic head and neck squamous cell cancer. Molecular and clinical oncology. 2015; 3:839-842.

34. Song Y, Liu H, Gao L, Liu X, Ma L, Lu M, Gao Z. Preoperative neutrophil-to-lymphocyte ratio as prognostic predictor for hypopharyngeal squamous cell carcinoma after radical resections. The Journal of craniofacial surgery. 2015; 26:e137-140.

35. Tu XP, Qiu QH, Chen LS, Luo XN, Lu ZM, Zhang SY, Chen SH. Preoperative neutrophil-to-lymphocyte ratio is an independent prognostic marker in patients with laryngeal squamous cell carcinoma. BMC cancer. 2015; 15:743.

36. Charles KA, Harris BD, Haddad CR, Clarke SJ, Guminski A, Stevens M, Dodds T, Gill AJ, Back M, Veivers D, Eade T. Systemic inflammation is an independent predictive marker of clinical outcomes in mucosal squamous cell carcinoma of the head and neck in oropharyngeal and nonoropharyngeal patients. BMC cancer. 2016; 16:124.

37. Fu Y, Liu W, OuYang D, Yang A, Zhang Q. Preoperative Neutrophil-to-lymphocyte Ratio Predicts Long-term Survival in Patients Undergoing Total Laryngectomy With Advanced Laryngeal Squamous Cell Carcinoma: A Singlecenter Retrospective Study. Medicine. 2016; 95:e2689.
38. Moon H, Roh JL, Lee SW, Kim SB, Choi SH, Nam SY, Kim SY. Prognostic value of nutritional and hematologic markers in head and neck squamous cell carcinoma treated by chemoradiotherapy. Radiotherapy and oncology. 2016; 118:330-334.

39. Nakahira M, Sugasawa M, Matsumura S, Kuba K, Ohba S, Hayashi T, Minami K, Ebihara Y, Kogashiwa Y. Prognostic role of the combination of platelet count and neutrophillymphocyte ratio in patients with hypopharyngeal squamous cell carcinoma. European archives of oto-rhino-laryngology. 2016; 273:3863-3867.

40. Nakashima H, Matsuoka Y, Yoshida R, Nagata M, Hirosue A, Kawahara K, Sakata J, Arita H, Hiraki A, Nakayama H. Pre-treatment neutrophil to lymphocyte ratio predicts the chemoradiotherapy outcome and survival in patients with oral squamous cell carcinoma: a retrospective study. BMC cancer. 2016; 16:41.

41. Rachidi S, Wallace K, Wrangle JM, Day TA, Alberg AJ, Li Z. Neutrophil-to-lymphocyte ratio and overall survival in all sites of head and neck squamous cell carcinoma. Head \& neck. 2016; 38:E1068-1074.

42. Sun W, Zhang L, Luo M, Hu G, Mei Q, Liu D, Long G, Hu G. Pretreatment hematologic markers as prognostic factors in patients with nasopharyngeal carcinoma: Neutrophillymphocyte ratio and platelet-lymphocyte ratio. Head \& neck. 2016; 38:E1332-1340.

43. Wong BY, Stafford ND, Green VL, Greenman J. Prognostic value of the neutrophil-to-lymphocyte ratio in patients with laryngeal squamous cell carcinoma. Head \& neck. 2016; 38:E1903-1908.

44. Tsai YD, Wang CP, Chen CY, Lin LW, Hwang TZ, Lu LF, Hsu HF, Chung FM, Lee YJ, Houng JY. Pretreatment circulating monocyte count associated with poor prognosis in patients with oral cavity cancer. Head \& neck. 2014; 36:947-953.

45. Laviano A, Meguid MM, Inui A, Muscaritoli M, RossiFanelli F. Therapy insight: Cancer anorexia-cachexia syndrome - when all you can eat is yourself. Nature clinical practice Oncology. 2005; 2:158-165.

46. Fearon KC, Voss AC, Hustead DS, Cancer Cachexia Study G. Definition of cancer cachexia: effect of weight loss, reduced food intake, and systemic inflammation on functional status and prognosis. The American journal of clinical nutrition. 2006; 83:1345-1350.

47. Donohoe CL, Ryan AM, Reynolds JV. Cancer cachexia: mechanisms and clinical implications. Gastroenterology research and practice. 2011; 2011:601434.

48. Grivennikov SI, Greten FR, Karin M. Immunity, inflammation, and cancer. Cell. 2010; 140:883-899.

49. Mantovani A, Allavena P, Sica A, Balkwill F. Cancer-related inflammation. Nature. 2008; 454:436-444. 